\title{
O laudo CMS e a potencial orientação jurisprudencial nos casos contra a Argentina junto ao CIRCI
}

\author{
Luis Fernando Corrêa da Silva Machado* \\ lf@mre.gov.br
}

\section{RESUMO}

A Argentina acedeu ao CIRCI em 1994, por acreditar que, desse modo, geraria maior influxo de investimento estrangeiro direto (IED) e encetaria vantagem competitiva importante no plano regional. Desde então, até setembro de 2004, cinco casos foram concluídos sob a jurisdição do Centro. Após a crise econômica de 2001, no entanto, mais de trinta casos estão sob a análise dos árbitros do CIRCI. Em vista disso, a reflexão se a adesão Argentina ao CIRCI trouxe benefícios para aquele país é pertinente de ser avaliada pelo Brasil. O artigo analisa, então, o laudo CMS expedido em 2005, por tratar-se do primeiro caso em que as questões de fundo referentes às medidas tomadas pelo governo argentino, em decorrência da crise econômica, foram avaliadas. Para tanto, faz-se breve pesquisa dos casos envolvendo a Argentina até a crise de 2001, salientando a dificuldade do estudo de sentenças arbitrais em razão da confidencialidade da arbitragem. Com base nas análises postas à disposição do público e de entrevistas com membros da Unidade de Assistência para a Defesa Arbitral criada pela Argentina, com vistas a centralizar a estratégia de defesa no CIRCI, depuram-se os argumentos do laudo CMS. O artigo aponta, portanto, para a estratégia errônea da Argentina em empregar a doutrina de emergência para quebrar direitos adquiridos e normas contratuais, uma vez que as medidas tomadas após a crise econômica se tornaram permanentes. Em vista disso, a responsabilidade deve ser atribuída aos governantes argentinos, que celebraram contratos cuja indexação estava atrelada a índice de outro país e cujo reajuste se baseava em outra moeda, em vez dos investidores internacionais que acreditaram nas potencialidades da economia argentina.

Palavras-chave: Centro Internacional para a Resolução de Conflitos sobre Investimentos (CIRC); Argentina; laudo CMS

\footnotetext{
* Diplomata; mestre em Relações Internacionais pela UnB; bolsista da Academia de Direito Internacional da Haia; bolsista da Comissão Jurídica Inter-Americana; ex-diretor regional para a América Latina da International Law Students Association.
} 


\title{
The CMS award and the Jurisprudential Potential Orientation in cases against Argentina together with the ICSID
}

\begin{abstract}
Argentina agreed with ICSID in 1994 for believing in this way she could generate a bigger influx of foreign direct investment (FDI) and would start an important competitive advantage in the regional plan. Since then, until September 2004, five cases were concluded under the jurisdiction of the Center. After the economical crisis in 2001, however, over thirty cases are under analysis of the arbiter of the ICSID. In consideration of this, the reflection and Argentina adhesion to the ICSID brought benefits for her, it is pertinent to be evaluated by Brazil. In this context, the aim of this article is to analyze the CMS award promulgated in 2005, the first case in which the issues referring to the measures taken by the Argentinian government in consequence of the economical crisis were evaluated. In such a way, a brief study of the cases was developed involving Argentina until the 2001 crisis and pointing out the difficulty of the study of arbitrary sentences in reason of confidentiality of the arbitrage. Based on the analyses disposal of the public and interviews with members of the Unit of Assistance for the Arbitral Defense created by Argentina with a view to centralize the strategy of defense in the ICSID, depurated the arguments of CMS award. As mainly conclusion, the article points out the strategy of Argentina in employing the doctrine of emergency to break acquired rights and contractual norms, since the measures taken after the economical crisis become permanent. In view of this, the responsibility should be attributed to the Argentinian governors that celebrated contracts whose indexation was associated with the index of the other countries and whose readjustment based on another currency, instead of international investors that believed in potentialities of Argentinian economy.
\end{abstract}

Key words: International Center for the Settlement of Investment Disputes (ICSID), Argentina, CMS award 


\section{INTRODUÇÃO}

No plano internacional, desde a década de 1960, com o objetivo de estimular a atração de Investimento Estrangeiro Direto (IED) ${ }^{2}$, além de contratos de investimento entre Estados e empresas, já se firmavam Acordos para a Promoção e Proteção Recíproca de Investimentos (APPIs) entre países industrializados e exportadores de capital, de um lado, e países em desenvolvimento - africanos e asiáticos, de outro, interessados em atrair IED, com vistas a prover segurança contra riscos não-comerciais aos investidores, ao estipular princípios, normas e remeter as contendas à esfera internacional. Somente a partir de meados da década de 1980, porém, os países latino-americanos passam a participar desse processo, pois, confrontados com a crise da dívida, passaram a exercer políticas voltadas para a maior integração à economia mundial. Esses países sempre foram reticentes quanto à adoção, em sua legislação interna, de convenções relativas ao IED e de solução de controvérsias internacionais. Nesse contexto, sobressai a doutrina Calvo ${ }^{3}$.

Diante desse cenário, também foi criado o Centro Internacional para a Resolução de Conflitos sobre Investimentos (CIRCI) ${ }^{4}$, cuja tarefa é prover facilidades para conciliação e arbitragem em relação às controvérsias sobre investimentos entre Estados-membros e nacionais de outros Estados-membros. De início, parece estranho que uma instituição financeira, mesmo que seja agência especializada das Nações Unidas, patrocinaria acordo sobre conflitos de investimentos entre Estados e investidores estrangeiros. No entanto, além de ser instituição de financiamento, o Banco Mundial, ao mesmo tempo, tem como uma das principais tarefas a promoção do desenvolvimento e acredita que o IED atua de forma benéfica para o crescimento das economias.

\footnotetext{
${ }^{2}$ O Fundo Monetário Internacional (FMI) define Investimento Estrangeiro Direto (IED), em seu Manual de balanço de pagamentos (1980), como: "o investimento realizado, a fim de adquirir interesse duradouro numa empresa que opera em economia diversa do investidor. Nesse tipo de investimento, a intenção do investidor é deter controle efetivo sobre a administração da empresa." [tradução livre]. Diferencia-se o IED do investimento em carteira (portfolio), em ações ou títulos, pelo caráter tendencialmente especulativo deste último. A rigor, o IED suscita diversas questões, por envolver o movimento de pessoas, a transferência de ativos de um Estado para outro, o que potencializa, a um só turno, as fontes de conflitos interestatais e as possibilidades de aproximação.

${ }^{3}$ Os Estados da América Latina eram defensores tradicionais da doutrina Calvo, que estipula estrangeiros só poderem ter os mesmos direitos que os nacionais e, dessa forma, só podem buscar medidas judiciais nos tribunais locais e conforme os dispositivos das leis nacionais. Atualmente, a doutrina Calvo apresenta consistência duvidosa, pois o exercício da proteção diplomática, ou seja, o fato de o país endossar a controvérsia de seus nacionais no plano externo, é direito do Estado.

${ }^{4}$ O CIRCI (em inglês ICSID - International Center for the Settlement of Investment Disputes) foi criado pela Convenção sobre Resolução de Conflitos relativos a Investimentos entre Estados e Nacionais de outros Estados, assinada em Washington em 18 de março de 1965, sob os auspícios do Banco Mundial.
} 
Até outubro de 2005, 142 países depositaram instrumentos de ratificação da convenção no CIRCI. Embora o número de casos trazidos ao Centro tenha sido pequeno, com a proliferação de Acordos Bilaterais de Investimentos ${ }^{5}$, a partir do final da década de 1980, quando a maioria submete qualquer controvérsia entre investidores e Estados à jurisdição do CIRCI, o número de caso aumentou substancialmente ${ }^{6}$. Com o divisor de águas da década de 1990 para a política direcionada ao IED na América Latina, os países do continente tornaramse parte da Convenção ${ }^{7}$, inclusive a Argentina em 1994, com a permanência da recusa brasileira $^{8}$. É o advento do direito transnacional, parte do direito internacional econômico, e a superação da fase na qual só se concebiam arbitragens intra-estatais.

A Argentina acedeu ao CIRCI por acreditar que, desse modo, geraria maior influxo de IED e encetaria vantagem competitiva importante no plano regional. Desde então, até setembro de 2004, cinco casos foram concluídos sob a jurisdição do Centro, e mais de trinta casos estão sob a análise dos árbitros do CIRCI. Em vista disso, a reflexão sobre se a adesão argentina ao CIRCI trouxe benefícios para aquele país é pertinente de ser avaliada pelo Brasil. Para países desprovidos de mercado nacional relevante, como o Uruguai e o Paraguai, é válida a construção de moldura jurídica e liberal relativa a investimentos. Nos casos brasileiro e argentino, por sua vez, deve-se ponderar se realmente serão vantajosas a assinatura de tais acordos e a submissão à jurisdição do Centro e às regras internacionais nessa matéria, em prol da atração de IED.

Vale ressaltar que, com o advento da crise financeira argentina de 2001, as demandas perante o CIRCI aumentaram de maneira vertiginosa, em decorrência da

\footnotetext{
${ }^{5}$ De acordo com dados da UNCTAD, existem mais de 2.000 acordos bilaterais de investimentos em vigor ao redor do mundo. Esses acordos geralmente concedem aos investidores tratamento justo e equânime, total proteção, compensação justa, pronta e adequada em caso de expropriações além de liberdade de transferência de ativos e remessas de lucros.

${ }^{6}$ Até outubro de 2005 foram concluídos 94 casos de arbitramento perante o CIRCI e 104 casos estavam pendentes junto ao Centro.

${ }^{7}$ Paraguai (1983), El Salvador (1984), Equador (1986), Honduras (1989), Chile (1991), Costa Rica (1993), Peru (1993), Argentina (1994), Bolívia (1995), Nicarágua (1995), Venezuela (1995), Colômbia (1997), Uruguai (2000), Guatemala (2003). Apesar de o México não ser Estado-membro do CIRCI, já iniciou seis procedimentos arbitrais no âmbito do NAFTA de acordo com as regras do Centro.

${ }^{8}$ Alguns dos motivos da recusa brasileira em assinar a Convenção do CIRCI, de cunho mais ideológico que jurídico, podem ser apreciados no parecer proferido pelo então consultor jurídico do Ministério das Relações Exteriores, Dr. Augusto de Rezende Rocha, em 1964. A atuação do Centro, segundo o parecer: "seria a consagração do imperialismo econômico e financeiro, ainda que disfarçada. (...) não é crível que qualquer Estado normalmente organizado, apresentando instituições asseguradoras de uma ordem jurídica primária, concorde, de boa mente, com sub-rogar funções públicas essenciais a um tribunal internacional, que, na sua organização e no seu funcionamento, será passível de sofrer influências prejudiciais à própria soberania desse Estado. (...) nunca o Governo brasileiro, em qualquer época, deixou de acolher, diplomática ou judicialmente, as reivindicações de meritous cases de estrangeiros que lhe fossem apresentadas. (SOARES, 1985, p. 80-82)
} 
reclamação dos investidores estrangeiros pela compensação das perdas sofridas pelas indústrias de gás, petróleo, telecomunicações, eletricidade e distribuição de água. Apenas em 2003, vinte corporações transnacionais recorreram a arbitragens contra a Argentina, sob a alegação da violação da garantia dos tratados de investimentos. Mais quatorze casos foram iniciados no CIRCI até outubro de 2005, o que levou à cifra de 34 casos atualmente sob julgamento. Ante esse quadro, o governo argentino, em 14 de outubro de 2004, emitiu comunicado, para solicitar o encerramento dos casos sem julgamento do mérito, uma vez que todos seriam injustificados, pois a Argentina estaria sob estado de calamidade pública, e não se aplicariam as disposições dos APPIs. Esses últimos acontecimentos tornam ainda mais relevante o estudo da experiência da Argentina para o Brasil e o Mercosul.

Neste trabalho, em primeiro momento, ao analisar os casos julgados pelo CIRCI envolvendo a Argentina até a crise de 2001, procurar-se-á destacar as principais contribuições para a consolidação da jurisprudência do Centro, pois, apesar de pouco numerosos, os laudos são estudados até hoje como leading cases na área, cuja repercussão condiciona outras nações a respeito de prós e contras de possível acessão ao Centro. Posteriormente, descrever-se-ão as razões apontadas pela literatura e por especialistas da crise argentina de 2001 e os litígios perante o CIRCI surgidos a partir de então. Para tanto, é necessário discorrer sobre os aspectos teóricos da modificação de contratos com Estados e os efeitos para a Argentina, dissecar a estratégia do país para a defesa perante as reclamações no CIRCI, o que engloba a criação de unidades para renegociação de contratos de serviços públicos e defesa arbitral. Em seguida, relatar-se-ão, brevemente, os casos iniciados com o fim da paridade cambial e os possíveis desdobramentos. Em outra seção, destacar-se-á o laudo “CMS Gás Transmission Company”, dada a importância para as orientações das futuras contendas com base nessa decisão. Por fim, serão tecidas considerações finais e condensadas as principais conclusões do artigo. 


\section{OS CASOS JULGADOS PELO CIRCI ENVOLVENDO A ARGENTINA ATÉ A CRISE DE 2001}

Antes da crise de 2001, cinco casos foram iniciados no âmbito do CIRCI envolvendo a Argentina ${ }^{9}$. Também foi julgado caso em que um nacional argentino, Emílio Agustín Maffezini, ganhou laudo contra o Reino da Espanha (doravante "Maffezini”) ${ }^{10}$. Entre os cinco procedimentos arbitrais, apenas em dois houve a condenação do Estado argentino, quais sejam, Compañia de Águas de Aconquija S.A. \& Vivendi Universal (doravante "Vivendi”), relacionado à rescisão de contrato de concessão de água na província de Tucumán, e Houston Industries Energy, Inc and others (doravante “Houston”), que diz respeito a conflitos na distribuição de energia elétrica na província de Santiago del Estero, registrado no Centro em 25 de fevereiro de 1998. Nos outros casos, após iniciado o procedimento arbitral, as partes chegaram a acordo, e o procedimento arbitral foi interrompido ${ }^{11}$ conforme a regra $43(1)^{12}$ dos procedimentos de arbitragem.

\section{DA QUESTÃO DA PUBLICIDADE DOS LAUDOS ARBITRAIS}

Cabe ressaltar que os termos em que foram concluídos os acordos não estão disponíveis ao público. Esse é direito inerente das partes na arbitragem, reforçado pelas regras de arbitragem do CIRCI. O artigo 48, inciso 5 da Convenção de Washington reza que: “O Centro não publicará o laudo sem o consentimento das partes”. Entretanto, o Centro poderá incluir, em suas publicações, extratos das normas jurídicas aplicadas pelo Tribunal. Os únicos laudos que estão disponíveis ao público dessa época são o Vivendi e a decisão preliminar sobre jurisdição do caso Lanco International Inc. (doravante “Lanco”), referente à disputa

\footnotetext{
9 A saber: Empresa Nacional de Electricidad S.A. (Caso n. ARB/99/4); Houston Industries Energy, Inc. and others (Caso n. ARB/98/1); Lanco International, Inc. (Caso n. ARB/97/6); Mobil Argentina S.A. (Caso n. ARB/99/1); Compañia de Águas del Aconquija S.A. \& Vivendi Universal (Caso n. ARB/97/3).

${ }^{10}$ Emilio Agustín Maffezini v. Reino da Espanha (Caso n. ARB/97/7).

${ }^{11}$ Embora a decisão jurisdicional do caso Lanco fosse disponibilizada ao público, tanto do caso Mobil - referente à tentativa da província de Salta de cobrar impostos sobre a renda bruta da empresa - quanto do caso Empresa Nacional de Eletricidade S.A. - relacionada à pretensão de cobrança da província de Neuquén de imposto de selos sobre contratos de abastecimento de energia elétrica celebrados por correspondência - nem a fase inicial dos procedimentos foi tornada pública.

${ }^{12}$ A regra 43(1) sobre acordo e descontinuidade dispõe que: "If, before the award is rendered, the parties agree on a settlement of the dispute or otherwise to discontinue the proceeding, the Tribunal, or the Secretary-General if the Tribunal has not yet been constituted, shall, at their written request, in an order take note of the discontinuance of the proceeding."
} 
sobre terminais portuários em Buenos Aires, iniciado em 14 de outubro de $1997^{13}$. Em recente pedido de parecer para a Procuradoria do Tesouro Nacional, tanto o laudo Vivendi quanto o laudo CMS Gás Transmission Company ${ }^{14}$ (doravante “CMS”), este último posterior à crise cuja análise mais apurada será realizada em seção abaixo, estão disponíveis ao público.

Em dezembro de 2003, por meio do expediente n. 2606, requereu-se o parecer da Procuradoria do Tesouro Nacional dos efeitos de publicar as decisões dos casos Vivendi e CMS. De início, o parecer ressaltou que a publicidade é erigida a princípio constitucional ${ }^{15}$. A rigor, a audiência pública encontra-se entre os direitos dos cidadãos ao controle e à participação dos aspectos reguladores dos serviços públicos, que deve ser prévia à decisão administrativa quando se tratar de atos de grave transcendência social. O princípio da publicidade, assim, é a regra. Excepcionalmente, em alguns casos que comprometam os direitos dos particulares ou em razão de defesa nacional, será válido romper esse postulado. Ao final, o parecer da Procuradoria conclui que a defesa do Estado argentino e as estratégias processuais utilizadas para a adequada defesa dos interesses nacionais não se encontravam comprometidas pela comunicação dos laudos à opinião pública.

Se é verdade que houve poucas decisões desse período e apenas uma disponível ao público alcançou a análise do mérito, tanto o caso Vivendi, cujo laudo condenou a República Argentina, quanto o caso Maffezini, que, apesar de não envolver a Argentina, conta com a participação de nacional argentino, transformaram-se em leading cases no direito internacional dos investimentos estrangeiros e em análise jurisprudencial obrigatória para aqueles que se propõem discutir a fundo a matéria. Por isso, cabe descrição apurada dos laudos e destaque das contribuições para o desenvolvimento do assunto.

\footnotetext{
${ }^{13}$ Nesse caso, o investidor de nacionalidade estadunidense alegou que a Argentina concedeu tratamento mais favorável ao competidor operador de outro terminal no mesmo porto. A Argentina, por sua vez, objetou a jurisdição do tribunal por o investidor ter participação minoritária e o contrato de concessão dispor que as controvérsias advindas do instrumento contratual deveriam ser submetidas à jurisdição local. Ambas as objeções foram rechaçadas pelo tribunal arbitral, ao considerar que o APPI entre os EUA e a Argentina não impõe a condição de o investidor ser acionista majoritário e por considerar o contrato de concessão acordo de investimento. $\mathrm{O}$ tribunal sublinhou ainda que o acesso à justiça local é inerente a qualquer sociedade comercial ou industrial, sem necessidade de acordo e que o APPI não exigia o esgotamento dos recursos internos.

${ }^{14}$ CMS Gás Transmission Company (Caso N. ARB/1/8).

${ }^{15} \mathrm{O}$ art. $1^{\circ}$ da Constituição Argentina proclama que: “La Nación Argentina adopta para su gobierno la forma representativa republicana federal, según lo establece la presente Constitución.”. Bidart (1998, p. 428) define a forma republicana por meio das seguintes características: a) divisão dos poderes; b) eleição popular dos governantes; d) publicidade dos atos do governo; e) responsabilidade dos governantes; f) igualdade perante a lei.
} 


\section{DO LAUDO VIVENDI}

Na arbitragem Vivendi, os demandantes eram investidores franceses na Argentina e iniciaram procedimento arbitral sob as regras do CIRCI, com base no APPI firmado entre os dois países em 19 de fevereiro de 1997. Por meio do APPI, a Argentina comprometeu-se a prover tratamento justo e eqüitativo e proporcionar proteção e plena segurança aos investimentos. Em paralelo, os demandantes tinham contrato de concessão com a província de Tucumán subscrito em 18 de maio de 1995. Ao mesmo tempo em que, conforme disposto no APPI, os investidores podiam escolher a arbitragem do CIRCI, segundo o contrato de concessão, as controvérsias derivadas desse instrumento jurídico deveriam ser submetidas, de forma obrigatória, aos tribunais contenciosos e administrativos de Tucumán.

A fim de provar as infrações do APPI, os demandantes basearam-se, principalmente, em atuações da província de Tucumán, o que, sob a perspectiva da responsabilidade estatal, não apresenta problema, pois a norma de direito internacional público atribui ao Estado federal às atuações de suas unidades. Assim, as alegações estavam estreitamente relacionadas com o contrato de concessão e a interferência do governo da província de Tucumán, tais como, redução de tarifas e abusos de autoridade. Por causa disso, a determinação das reclamações derivadas do tratado requereu avaliação da conduta das partes no contrato de concessão.

No laudo Vivendi, de 21 de novembro de 2000, o tribunal arbitral ${ }^{16}$, em contrário ao entendimento já emanado no caso Lanco, considerou que as pretensões na arbitragem consistiam em violações contratuais, apesar de apresentadas no espectro do APPI. Recusouse, portanto, a analisar o caso sob o argumento de que o investidor deveria, primeiro, respeitar os mecanismos contratuais pactuados, ou seja, deveria recorrer às cortes locais. Ao emitir essa decisão, o tribunal engendrou a discussão sobre o investidor poder enquadrar a interferência do ente estatal no contrato de concessão como violação de APPI, em vez de violação de dispositivos contratuais.

Posteriormente, o laudo foi anulado, em parte, por comissão ad hoc ${ }^{17}$, em 3 de julho de 2002, de acordo com procedimento contemplado no artigo 52 da Convenção de

\footnotetext{
${ }^{16}$ Integrado por Francisco Rezek (Brasil), na qualidade de presidente, e Thomas Buergenthal e Peter D.Trooboff (Estados Unidos), como árbitros restantes.

${ }^{17}$ Integrado pelo professor James R. Crawforde (Austrália), o professor José Carlos Fernández Rozas (Espanha) e Ives Fortier (Canadá), designado presidente. A participação de Fortier foi objeto de questionamento por parte da Argentina, recusada pelo Comitê mediante a decisão datada de 3 de outubro de 2001.
} 
Washington $^{18}$, com base no entendimento de que a pretensão calcada no descumprimento do APPI pode, embora não necessariamente, imiscuir-se com pretensão fundamentada em contrato, o que permite, então, ao investidor optar entre a apresentação perante cortes locais ou recorrer diretamente à instituição da arbitragem. Por isso, o tribunal arbitral incorreu em julgamento infra petita, ao não decidir se o comportamento do governo da província de Tucumán poderia ser considerado infração ao APPI entre França e Argentina. Segundo a comissão ad hoc:

“§102. En opinión del comité, un tribunal Ciadi que tenga jurisdicción con arregla a un TBI respecto a una reclamación basada en una estipulación sustantiva de dicho TBI, no podrá desestimar la reclamación sobre la base de que podría o debería haber sido tratada por un tribunal nacional... § 105. (...) Una cosa es ejercer una jurisdicción contractual - discutiblemente cedida con carácter exclusivo a los tribunales administrativos de Tucumán en virtud del contrato de concesión - y otra tener en cuenta los términos de un contrato al establecer si ha habido una infracción de una norma diferente de derecho internacional, tal como la reflejada en el artículo $3^{\circ}$ del TBI.”

Como contribuição à jurisprudência derivada do Centro, o laudo Vivendi assume particular relevância por distinguir entre questões contratuais e questões regidas por tratados sobre investimentos e ao configurar que a violação de APPI é matéria de consideração obrigatória por parte de tribunais arbitrais no âmbito do CIRCI. Ao discernir a origem das obrigações, seja com base em contrato, seja com base em tratado, o tribunal ratificou o entendimento de que ambos os compromissos sejam independentes. Por fim, ainda que os atos originários da violação de tratados tenham sido perpetrados por uma província, atribuiu a responsabilidade internacional ao governo federal, em consonância com o entendimento cristalizado pela doutrina internacional.

\section{DO LAUDO MAFFEZINI}

No caso Maffezini, cujo propósito era considerar se as atuações de organismos estatais regionais poderiam ser atribuídas ao Reino da Espanha, reafirmou-se a doutrina dominante de direito internacional público de que as ações de órgãos internos do Estado ensejam responsabilidade estatal. Também se estipulou que, se a pretensão das partes for

\footnotetext{
${ }^{18}$ O pedido de anulação foi motivado com base em três das cinco causas contempladas no art. 52 (1): (i) que o tribunal arbitral extrapolou suas faculdades; (ii) que houve quebra grave de norma procedimental; (iii) que se omitiu expressar os motivos sobre os quais se fundamentou o laudo.
} 
baseada em fontes contratuais em vez de tratado, devem cingir-se aquelas presentes no contrato. Os procedimentos arbitrais iniciaram-se ante a denúncia por parte do Sr. Maffezini da existência de controvérsia em decorrência do tratamento recebido pelo investimento em empresa de fabricação e distribuição de produtos químicos na região espanhola da Galícia.

Nessa arbitragem ${ }^{19}$, Maffezini, investidor argentino, iniciou procedimento de arbitragem contra a Espanha, sem recorrer previamente às cortes locais espanholas, conforme disposto no artigo X(2) do APPI entre os dois países, pois invocou a aplicação de cláusula de nação mais favorecida, ao recorrer às disposições do APPI entre o Chile a Espanha, cujo texto prevê a possibilidade de recurso imediato à arbitragem do CIRCI. Sob essa perspectiva, o tribunal arbitral declarou-se competente sobre a controvérsia, na medida em que existiam outros APPIs mais favoráveis ao investidor que o tratado em tela, ao prever recurso direto à arbitragem e, segundo a cláusula de nação mais favorecida, seriam aplicáveis à controvérsia.

A decisão Maffezini outorga aos investidores a segurança de desfrutar do direito ao foro arbitral, sempre que assim o desejar. Muitos analistas criticam a decisão Maffezini por multilateralizar o recurso à arbitragem, ou seja, sempre que houver algum APPI celebrado por determinado país cujo texto prevê a arbitragem, o investidor estrangeiro terá o direito de invocá-la, independentemente de o tratado pactuado com o seu país não dispor dessa cláusula.

A par disso, o caso Maffezini sobressai por ser a primeira vez que investidor proveniente de país em desenvolvimento invoca as disposições de APPI contra nação desenvolvida, com base na violação de normas relativas a tratamento concedido a investimento. De fato, é curioso que, embora poucos, os laudos envolvendo a Argentina ou os nacionais argentinos tenham ganhado projeção pelas questões controversas suscitadas. Tal fenômeno voltou à tona, após a avalanche de ações impetradas no início de 2002.

\section{A CRISE ARGENTINA DE 2001 E OS LITÍGIOS PERANTE O CIRCI}

Quando, em 1910, por ocasião da comemoração do centenário da independência, a Argentina respondia por 50\% do Produto Interno Bruto da América Latina, o futuro dessa nação parecia auspicioso. Em 1928, a Argentina era a sexta potência econômica mundial e

\footnotetext{
${ }^{19}$ Integrada pelos seguintes árbitros: professor Fancisco Orrego Vicuña (Chile), na qualidade de presidente, juiz Thomas Buergenthal (Estados Unidos), designado pelo Sr. Maffezini e Maurice Wolf (Estados Unidos), designado pela Espanha.
} 
manteve-se, ao longo de todo o século XX, como um dos países mais bem-sucedidos do continente. Ao consolidar uma estratégia de sustentar a economia agrário-exportadora, a qual apresenta vantagens comparativas significativas, a Argentina, no entanto, sofreu o duro golpe da deterioração das cotações das commodities agrícolas na segunda metade do século XX, somada à elevação de preço dos manufaturados, o que levou à queima das reservas internacionais. Em paralelo, na segunda metade do século XX, a Argentina enfrentou a ditadura militar no campo político e, em particular, na década de 1980, a hiperinflação no campo econômico, além de generalizada perda da competitividade da indústria. Todos esses fatores abalaram a economia e a moral do povo argentino, que jamais recuperou o ambiente dos anos dourados do início do século XX.

Com o Plano de Conversibilidade, implantado pelo Ministro Cavallo na década de 1990, em decorrência da ascensão ao poder do presidente Carlos Menem, o país apresentou crescimento significativo e curiosa combinação de estabilidade de preços com instabilidade de outros fatores macroeconômicos, o qual o mais pernicioso veio a ser o aumento da dívida pública, principal financiador da estabilidade, ainda que a relação entre dívida e PIB tenha caído de 92\%, em 1989, para 45\%, em 1991, e 27\%, em 1993, só vindo a crescer mais ao final da década. Ao mesmo tempo, entretanto, a desigualdade social continuou a expandir-se, e, a partir de 1998, a economia começou a encolher aceleradamente. Em 2001, houve a grande débâcle do sistema de conversibilidade, responsável pela elevação da miséria, do caos social e pela estagnação da economia argentina. Além disso, engendrou problemas jurídicos, na medida em que a conversibilidade significou a dolarização de facto dos contratos existentes por prazo indefinido.

Em decorrência da queda substancial do poder aquisitivo do povo argentino, com vistas a amenizar a crise, o governo não permitiu o aumento de tarifas públicas. Como a maioria dos contratos de concessões, licenças ou autorizações celebrados pelo governo argentino com investidores estrangeiros ao longo da década de 1990 estipulavam a indexação das tarifas dos contratos pelo producer price index ${ }^{20}$ (PPI) dos Estados Unidos e a correção atrelada ao dólar norte-americano era convertida à moeda local ao tempo da fatura, os investidores alegam ter incorrido em perdas, sobretudo ante a pesificação das tarifas resultantes do colapso da conversibilidade. Após tratativas com o governo local, diversas

\footnotetext{
${ }^{20}$ Índice cujo propósito é mensurar a alteração média dos preços dos produtos vendidos por produtores de bens e serviços num mês. Os preços referem-se à primeira transação comercial, e o índice propõe-se a medir a inflação mensal.
} 
empresas iniciaram procedimentos arbitrais junto ao CIRCI, a fim de reaver as perdas do período.

Trata-se de 34 casos até o momento ${ }^{21}$ que podem levar a Argentina ao pagamento de indenizações no montante de mais de 17 bilhões de dólares. É volume sem precedentes de litígios iniciados contra um só país na história do Centro. Para uma nação debilitada economicamente, esse sangramento de divisas pode aprofundar, ainda mais, a penúria do povo. Por isso, as autoridades locais conferiram significativos esforços com o propósito de defender o país seja por meios de negociação com os investidores, seja pela defesa dos interesses argentinos perante tribunais arbitrais.

Nesse sentido, foi criada em 2003 a Unidade de Renegociação de Contratos e Serviços Públicos (UNIREN), cujo objetivo é a elaboração de marco regulatório geral para os serviços públicos ${ }^{22}$, bem como a renegociação dos contratos em curso. Também no intuito de proteção do interesses argentinos, foi criada, no mesmo ano, a Unidade de Assistência para a Defesa Arbitral (UNADAR), com vistas a centralizar a estratégia de defesa no CIRCI, além de outros tribunais arbitrais. Para melhor compreensão das razões dos investidores e dos desdobramentos do julgamento desses casos, cabe análise mais apurada das implicações jurídicas e do trabalho efetuado pelo UNIREN e do papel da UNADAR, além das pretensões argentinas.

\section{MODIFICAÇÃO E RESCISÃO DE CONTRATOS COM ESTADOS}

Além do risco econômico, quando determinada empresa visa a estabelecer-se em certo país, há o risco político. Graças à evolução do direito internacional sobre investimentos, as empresas, por meio da assinatura de tratados bilaterais entre seus países natais e outros Estados, instituem a alternativa do recurso à arbitragem com o intuito de submeter as controvérsias à justiça imparcial. Para tanto, é necessário que haja ou tratado, ou compromisso arbitral inserido no contrato entre particular e Estado. Em razão disso, decorre a

\footnotetext{
${ }^{21}$ Outubro de 2005.

${ }^{22}$ O que vem ao encontro do disposto no art. 42 da Constituição Federal: “... La legislación establecerá procedimientos eficaces para la prevención y solución de conflictos, y los marcos regulatorios de los servicios públicos de competencia nacional, previendo la necesaria participación de las asociaciones de consumidores y usuarios y de las provincias interesadas, en los organismos de control.”
} 
importância em distinguir as obrigações derivadas do texto de convenção ou do texto de contrato.

Resta saber se o Estado pode modificar unilateralmente o que foi convencionado em virtude da soberania ou se predomina o princípio do que foi pactuado, pacta sunt servanda. Trata-se de questão pacificada na doutrina. Em função da soberania, o Estado pode tanto mediante alterações na legislação quanto no uso das prerrogativas modificar unilateralmente ou mesmo rescindir o contrato antes do tempo. Nem o interesse superior do Estado, nem a ordem pública podem ser sacrificados diante do interesse do particular.

Há, contudo, limites. Sob todas as condições, salvaguarda-se o equilíbrio contratual, ou seja, só pode ocorrer modificação ou rescisão em contrapartida de indenização justa. Assim, não é o contrato, porém a equação financeira que é considerada intangível. Além disso, as concessões econômicas conferidas por lei ou contrato integram o conceito de investimento, tal como descrito nos APPIS celebrados pela República Argentina. Em vista disso, o Estado argentino, após a crise econômica, tenta renegociar os contratos de concessão de serviços públicos pactuados com entes estrangeiros. Muitos deles, ainda insatisfeitos, preferiram, porém, fazer uso da justiça arbitral para reaver as perdas sofridas.

\section{EXPROPRIAÇÃO REGULATÓRIA OU INDIRETA}

Se, por um lado, a situação econômica da Argentina requer a compreensão do investidor internacional, por outro, no domínio dos serviços públicos, é notória a vulnerabilidade ante o oportunismo político dos Estados. Por exemplo, logo após a efetivação do investimento, o governo receptor pode tentar fixar novos preços, exigir novos investimentos, controlar o movimento de capitais. Com efeito, ocorre a expropriação regulatória ou indireta ${ }^{23}$.

\footnotetext{
${ }^{23}$ A própria Corte Suprema da Argentina já analisou a questão no caso “Compañia de Tranvías Anglo Argentina c. Nación Argentina" quando sustentou que: "en suma el Poder público - como Estado general - pudo seguir esa política [de congelamiento de precios] si así lo creyó conveniente o necesario, pero lo que no pudo - como concedente - fue realizar a costa del patrimonio afectado al servicio. Este, de acuerdo com lo resuelto por la Corte, se encuentra bajo el amparo de la proteccion que el art. 17 de la Carta fundamental dispensa a la propiedad. De modo pues que si el Poder Ejecutivo no quiso autorizar aumentos de tarifas - o subvencionar al concesionario si preferia - quedó obligado a indemnizar; deber que tiene fundamento en el principio de expropriación contenido en el mismo precepto constitucional."
} 
Trata-se de instituto de direito internacional, segundo o qual a expropriação pode adquirir o caráter indireto mediante a privação do uso ou do benefício econômico razoável derivado da propriedade ${ }^{24}$. Ao propugnar-se esse conceito, a expropriação adquire natureza extensiva. Por isso, praticamente qualquer medida governamental, por exemplo, aumento de impostos, regulação ambiental, ou a revogação de licença, pode ensejar, sob certas circunstâncias, expropriação ${ }^{25}$. Toda vez que ficar caracterizada expropriação, o Estado deve prover indenização pronta, adequada e efetiva, ou seja, correspondente ao valor do mercado do investimento na data da apropriação, em moeda conversível.

Esse sentido tem entendido a jurisprudência dos tribunais arbitrais no âmbito do CIRCI. Tempone (2003, p. 61) relata o caso "Liberian Eastern Timber Corporation (LETCO) v. Governo da República da Libéria” (Caso n. ARB/83/2), cujos árbitros consideraram a revogação pela Libéria de contrato de concessão, que outorgava a exclusividade das atividades madeireiras pelo período de 20 anos à empresa francesa, de expropriação ou de nacionalização ilegal, já que houve cerceamento dos direitos de propriedade. Com efeito, para que o investidor estrangeiro invoque tratado de promoção de investimentos, não é necessário estar diante de expropriação direta, nacionalização ou confisco. Basta, porém, medida similar $^{26}$, por exemplo, modificação das condições contratuais ou progressiva regulamentação por parte do Estado receptor do investimento, que acarrete algum tipo de implicação

\footnotetext{
${ }^{24}$ O CIRCI já corroborou essa assertiva no caso n. ARB/97/1 "Metalclad Corporation v. Estados Unidos Mexicanos”. Laudo de 30 de agosto de 2000.

${ }^{25}$ No caso Starret, do Tribunal Irã-Estados Unidos, citado por Videla (199, p. 48), estabeleceu-se que: "no se discute que en este caso el Gobierno de Irán no sancionó ninguna ley o decreto de acuerdo al cual el Zomorod Project o Shah Goli expresamente haya sido nacionalizado o expropiado. Sin embargo, es reconocido en el derecho internacional que medidas tomadas por el Estado pueden interferir con derechos de propriedad en tal extensión que estos derechos se convertirán en tan inútiles que se juzgan que han sido expropriados, aun cuando el Estado no haya tenido el propósito de expropiarlos y el título de propiedad formalmente se mantenga en cabeza del propietario original."

${ }^{26}$ A Corte Suprema da Argentina adotou orientação similar, na sentença do caso "Provincia de San Luis c. P. E. N. -Ley 25561, Dto. 1570/01 y 214/02 s/ amparo)”, de 5 de marzo de 2003, declarou: “...no es ocioso recordar, como lo ha puntualizado desde antaño el Tribunal, que la restricción que impone el Estado al ejercicio normal de los derechos patrimoniales debe ser razonable, limitada en el tiempo, un remedio y no una mutación en la sustancia o esencia del derecho adquirido por sentencia o contrato... De ahí que los mecanismos ideados para superar la emergencia están sujetos a un límite y éste es su razonabilidad, con la consiguiente imposibilidad de alterar o desvirtuar en su significación económica el derecho de los particulares... ; y no es dudoso que condicionar o limitar ese derecho afecta a la intangibilidad del patrimonio y obsta al propósito de afianzar la justicia.”
} 
econômico-financeira à propriedade estrangeira ${ }^{27}$.

Em função disso, ao longo do processo negociador, o governo argentino deve agir no sentido de coibir ao máximo os comportamentos oportunistas, a fim de manter a reputação internacional, sob pena de afugentar futuros investidores em áreas nas quais o país é carente de recursos. Afinal, para investir em serviços públicos, o governo deixará de investir em outros campos. Não compensa, portanto, primar por interesses de curto prazo eleitorais em detrimento dos de longo prazo, ou seja, os de fornecer à população argentina serviços públicos de qualidade. Desse modo, quando configurada a expropriação indireta, o governo deveria indenizar os danos causados aos investidores.

\section{A UNIDADE DE RENEGOCIAÇÃO DE CONTRATOS DE SERVIÇOS PÚBLICOS}

Atualmente, o Estado argentino envida esforços em processo de renegociação dos contratos de obras e serviços públicos celebrados com as companhias concessionárias de serviços públicos, cujas tarifas haviam sido “pesificadas” e congeladas. A renegociação realiza-se no âmbito da emergência pública e da reforma do regime de câmbio estabelecida pela Lei $25.561 / 02^{28}$. O Executivo estabeleceu as distintas fases do processo ${ }^{29}$, e o Ministério da Economia é a autoridade encarregada de conduzir as gestões que criou, por sua vez, a Unidade de Renegociação de Contratos de Serviços Públicos ${ }^{30}$.

Tal Unidade recebe as propostas das companhias e avalia-as, bem como elabora marco regulatório geral dos serviços públicos. Deve, no âmbito de sua atuação, encaminhar informe final para a aprovação do Ministro da Economia. A seu turno, o Ministro da Economia deve aprovar ou não o conteúdo da proposta renegociada. Até o momento, o governo exige que as empresas desistam dos procedimentos junto ao CIRCI como précondição para iniciar as negociações do aumento de tarifas. Em vista dessa posição, embora

\footnotetext{
${ }^{27}$ Há garantias tanto constitucionais, qual seja, o art. 17 que estabelece: "La propiedad es inviolable, y ningún habitante de la Nación puede ser privado de ella, sino en virtud de sentencia fundada en ley." quanto na legislação infraconstitucional que rege contratos e obrigações, a saber, o art. 1197 do Código Civil argentino: "Las convenciones hechas en los contratos forman para las partes una regla a la cual deben someterse como a la ley misma."

${ }^{28}$ Renovada pelo período de mais um ano, em 17 de dezembro de 2004, pelo Congresso Argentino, por meio da Lei 25.790 e estendido até 31 de dezembro de 2005, mediante a Lei 25.972.

${ }^{29}$ Decretos 293/2002, 370/2002, 1090/2002, entre outros.

${ }^{30}$ Por intermédio da Resolução ME 20/2002. Criada, posteriormente pelo Decreto 311/2003, emitido em 3 de julho de 2003, publicado no Boletim Oficial em 4 de julho de 2003.
} 
não estejam predispostas a desistir, as empresas privadas estrangeiras, por enquanto, consideram a possibilidade de suspender os procedimentos.

Nesse contexto, o governo negocia mais de 60 contratos de serviços públicos. A rigor, isso já deveria estar concluído, mas projeta-se que se estenda até o começo de 2006. No âmbito dessas renegociações, foram assinados acordos temporários, em particular com os setores de telecomunicações e águas. Por causa desses esforços, as empresas concordaram em suspender os procedimentos perante os tribunais arbitrais, bem como se comprometeram em investir certos montantes com vistas a melhorar a qualidade dos serviços prestados, além de aceitar o congelamento de tarifas até que contratos de longo prazo sejam firmados. Em paralelo à renegociação, a República Argentina deve responder às demandas impetradas no CIRCI, na medida em que se vislumbra a internacionalização desses contratos diante da cláusula dos APPIs que remete o litígio à arbitragem internacional.

\section{A UNIDADE DE ASSISTÊNCIA PARA A DEFESA ARBITRAL}

Em razão dos interesses envolvidos e das graves repercussões para a economia argentina, além de que, apesar de as controvérsias iniciadas perante o CIRCI pertencerem a diversos setores, as causas originárias residem precipuamente nos efeitos das disposições de emergência pública sancionadas pelo Congresso Nacional e pelos Governos Provinciais, o Poder Executivo Federal criou agente único com vistas a defender os interesses argentinos. Trata-se da UNADAR, criada pelo Decreto 965/2003 ${ }^{31}$, cujo escopo é a elaboração de estratégias e linhas de negociações amistosas e de defesa em controvérsias com fundamento nos APPIs.

A Unidade funciona no âmbito de Procuradoria do Tesouro Nacional com os profissionais da área de assuntos internacionais ${ }^{32}$. Seus integrantes contam com um responsável pela área de assuntos internacionais da Procuradoria do Tesouro Nacional, representantes do Ministério da Economia e Produção, representantes do Ministério de Programação Federal, Investimentos Públicos e Serviços, representantes do Ministério de Relações Exteriores, Comércio Internacional e Culto. O mesmo decreto que criou a

\footnotetext{
${ }^{31}$ Emitido em 24 de outubro de 2003 e publicado no Boletim Oficial em 29 de outubro de 2003.

${ }^{32}$ A equipe da UNADAR é coordenada atualmente pelo Dr. Jorge Barraguirre.
} 
UNADAR revogou o Decreto 926/2003 ${ }^{33}$, que dispunha sobre a criação de organismo para realizar negociações amistosas com investidores estrangeiros. Nota-se, assim, ponto de inflexão da política argentina na medida em que as negociações amistosas falharam e tornouse necessário romper com o paradigma anterior e estabelecer ferramenta unificada para a representação do país junto aos tribunais arbitrais.

As disposições do decreto ainda permitem à UNADAR interagir com a Unidade de Renegociação e Análise de Contratos e Serviços Públicos, bem como com órgãos e entes estatais envolvidos em processos arbitrais. Há ativa participação com as províncias. A UNADAR está autorizada a requerer a informação necessária a organismos nacionais, provinciais e municipais, assim como a entidades que achar conveniente. Como a República Argentina não creditou nenhuma subdivisão política ou organismo público para atuar junto ao $\mathrm{CIRCI}^{34}$, faz-se necessária a articulação por parte da Procuradoria do Tesouro da Nacional ${ }^{35}$, a fim de representar os interesses do país. Desse modo, toda a linha de defesa argentina apresenta congruência e similaridade, o que permite melhor análise e prever quais os próximos passos nos casos iniciados com o fim da paridade cambial.

\section{OS CASOS INICIADOS COM O FIM DA PARIDADE CAMBIAL E OS POSSÍVEIS DESDOBRAMENTOS}

Pelo advento da crise argentina, diversos casos foram iniciados perante o CIRCI (cf. tabela $3^{36}$ ). Até outubro de 2005, eram 34 casos pendentes, cujas companhias atuam, sobretudo, em áreas de prestação de serviços de água, gás, telecomunicações e eletricidade. Na maioria deles, as alegações são praticamente idênticas. Os investidores reclamam que a suspensão e a posterior derrogação dos ajustes tarifários pelos índices de preços dos Estados Unidos, da maneira contemplada nos contratos de concessão de serviços públicos, prejudicam os investimentos. Ao impedir o reajuste, o Ministério Público da Argentina fundamentou que tais ações violariam a Lei de Conversibilidade sancionada em 1991. Outro descumprimento

\footnotetext{
${ }^{33}$ Emitido em 21 de abril de 2003 e publicado no Boletim Oficial em 22 de abril de 2003.

${ }^{34} \mathrm{O}$ art. 25 da Convenção de Washington permite que subdivisões políticas ou organismos públicos atuem perante o Centro se forem acreditados pelos respectivos governos nacionais.

${ }^{35}$ Nesse sentido, o art. 99, inc. 11 da Constituição da Argentina delega ao poder Executivo as atribuições: "Concluye y firma tratados, concordatos y otras negociaciones requeridas para el mantenimiento de buenas relaciones con las organizaciones internacionales y las naciones extranjeras, recibe sus ministros y admite sus cónsules.”

${ }^{36}$ Para os casos iniciados sob as regras da UNCITRAL e da Câmara de Comércio Internacional (CCI).
} 
contratual refere-se à eliminação de tarifas em dólares, cuja motivação foi a Lei 25.561, bem como há o aspecto da restrição de transferências ao exterior.

Ao sofrer essas mudanças nas condições das concessões, os investidores estrangeiros alegam a expropriação indireta do investimento sem a adequada indenização e a violação do tratamento justo eqüitativo em descumprimento das proibições constantes nos APPIs firmados pela Argentina. Resta claro, então, que mudanças nas condições tarifárias pactuadas ou a rescisão contratual antes do tempo convencionado ensejam a violação dos tratados bilaterais sobre investimentos, nos quais a Argentina se comprometeu a não expropriar sem indenização.

Em contrapartida, no momento das decisões, os tribunais arbitrais devem considerar a falta de realização dos investimentos pactuados com as empresas estrangeiras. Trata-se de questão vital no instante de determinar o valor da compensação adequada pela alteração do regime cambial e do ajuste de tarifas. A esse respeito, também devem analisar-se outras questões, como a ilicitude de lucros excessivos obtidos por intermédio de concessões monopólicas.

Ao tentarem enquadrar as medidas tomadas pela Argentina como arbitrárias, os investidores alegam a violação da obrigação dos Estados de não impor entraves seja à gestão, seja à operação do investimento, em decorrência de medidas arbitrárias ou discriminatórias ${ }^{37}$. Na área de proteção ao IED, a CIJ formulou, no caso ELSI, um teste da arbitrariedade de atos estatais, quando explicou: “A arbitrariedade não se refere a algo que se opõe à norma legal, como se fosse simplesmente oposto à legalidade (...) É uma inobservância intencional do devido processo legal, um ato que impressiona ou, ao menos, surpreende o sentido do decoro jurídico.”38 $\mathrm{Na}$ prática, se a medida é ou não arbitrária, deve ser analisada à luz das circunstâncias particulares de cada caso.

Sobre o assunto, a jurisprudência ${ }^{39}$ internacional apregoa que a mudança no marco legal, ao tornar impossível a preservação ou a continuação dos compromissos contratuais motivadores do investimento, é considerada incompatível com as cláusulas de plena proteção e segurança dispostas nos APPIs. A prática arbitral propõe o respeito pelos direitos adquiridos

\footnotetext{
${ }^{37}$ Nesse sentido, o art. II(2)(b) do tratado entre Estados Unidos e Argentina discorre sobre essa regra: "Ninguna de las partes menoscabará, en modo alguno, mediante la adopción de medidas arbitrarias o discriminatorias, la dirección, la explotación, el mantenimiento, el uso, el usufructo, la adquisición, la expansión o la liquidación de las inversiones."

${ }^{38}$ Caso ELSI. Sentença de 20 de julho de 1989, ICJ Rep., 1989, p. 76.

${ }^{39}$ CME República Tcheca B.V. (Holanda) v. República Tcheca. Laudo parcial de 13 de setembro de 2001 de tribunal constituído sob as regras da UNCITRAL.
} 
em relação à autorização para investir concedida pelo Estado receptor. Assim, resta pouca dúvida acerca da responsabilidade da Argentina, a despeito das medidas procrastinatórias da defesa; o que está sob a mesa de discussão repousa muito mais sobre o montante da indenização.

Como já mencionado, a expropriação indireta, conforme princípios de direito internacional, enseja reparação. Não há, contudo, critérios claros e categóricos a propósito do tema. Tampouco os APPIs firmados pela República Argentina enumeram as ocasiões em que se gera responsabilidade estatal. Com efeito, qualquer medida tomada pelo Estado não dá lugar imediato à indenização. Deve-se valorar o grau de interferência no direito de propriedade, a duração da regulação, na medida em que os Estados podem adotar medidas temporárias sob certas circunstâncias, o contexto em que o Estado se baseou para adotar as medidas que devem pautar-se pelo bem-estar geral dos cidadãos e por critérios de ordem pública.

Em vista disso, o Estado argentino alega que as medidas adotadas tiveram como único intento superar a aguda crise econômica que assolou o país. Em nenhum momento, portanto, houve a intenção de discriminar ou prejudicar o investidor estrangeiro. Ainda assim, o prejuízo dos investidores em função do estado de emergência é patente. Ao analisar o período de vigência das medidas de 2002 até os dias de hoje, com sucessivas reedições da Lei de Emergência, questiona-se também se seriam temporárias. Apesar de cada caso ter de ser analisado de forma distinta, já que envolve questões diversas, não se podem negar os prejuízos sofridos mediante a expropriação indireta, pois o que foi pactuado não foi cumprido.

Não se podem atribuir erros de política econômica perpetrados pelo governo argentino aos investidores. Trata-se do problema maior de indexação da economia, cujos efeitos funestos levaram o país a uma das maiores crises de sua história. Ao atrelar contratos vigentes por tempo indeterminado à moeda estrangeira, o governo congelou o sistema cambial, sem prever a insustentabilidade dessa decisão a longo prazo.

As sentenças condenatórias dos tribunais arbitrais internacionais são diretamente executáveis na Argentina e, pela índole da matéria litigiosa, resulta que contenha caráter pecuniário. Por isso, a condenação no âmbito do CIRCI, estimada no valor aproximado de US\$ 17 bilhões, irá pesar diretamente sobre as finanças públicas. Em Estado sem recursos genuínos para cumprir seus compromissos e a despeito do fim da moratória de três anos em 2005 quando concluiu a reestruturação recorde da dívida de US\$ 103 bilhões, cabe saber como as condenações serão pagas. 
Pode-se inferir que acontecerá da mesma maneira de sempre, ou seja, com emissão de bônus, títulos públicos e letras do Tesouro Nacional. Se, por um lado, os investidores esperam que o Banco Mundial, do qual o CIRCI faz parte, defenda os tratados, por outro, o Banco possui a tarefa de promoção do desenvolvimento e reconhece que a Argentina está numa situação insolvente e precisa de mais fundos. Segundo Casey (2005), analistas acreditam que o governo dos Estados Unidos pode endurecer e aplicar a chamada Emenda Helms Burton. Desse modo, exigirá o bloqueio de dinheiro e de ajuda tanto bilateral quanto multilateral se, comprovadamente, expropriaram-se ativos de investidores estadunidenses. Casey sublinha que, em sua defesa, a Argentina deve citar precedente dos próprios Estados Unidos: a decisão da Suprema Corte americana de que uma decisão do presidente Richard Nixon, em 1973, para abandonar o padrão-ouro foi legítima política econômica de país soberano, e não a expropriação dos ativos de investidores estrangeiros.

Outra possível defesa não explorada pelos representantes da Procuradoria do Tesouro da Nação versa em justificar os atos do Estado pela impossibilidade de respeitar, de outra forma, as obrigações referentes ao direito internacional dos direitos humanos. Trata-se, entre outros argumentos, de alegar que as obrigações internacionais da Argentina em matéria de direitos humanos, dado que a Carta das Nações Unidas faz menção à obrigação de respeitar os direitos humanos e que, no artigo 103, eleva esse instrumento à escala hierarquicamente superior aos outros instrumentos de direito internacional. Em razão disso, as obrigações em matéria de direitos humanos deverão ser respeitadas em caráter prioritário, em caso de conflito proveniente do direito dos investimentos. Embora não tenha sido feito anteriormente, seria interessante verificar qual é a posição de um tribunal arbitral a respeito do assunto.

De qualquer maneira, o governo argentino, seja para ganhar tempo, seja para forçar os investidores a abandonar os procedimentos arbitrais e impelir a renegociação contratual, sustenta que, em nenhum dos casos iniciados perante o CIRCI, produziu-se ato expropriatório, nem houve discriminação em relação aos investidores estrangeiros e nacionais. Tampouco se dificultou o acesso à justiça argentina, razões que poderiam ter dado lugar ao recurso arbitral.

Ao firmarem os contratos de concessão, os investidores estrangeiros pactuaram expressamente recorrer à jurisdição argentina, com a renúncia de qualquer outro foro no que se refere às divergências a respeito de questões contratuais. Por isso, a defesa alega que não cabe o subterfúgio de iniciar procedimentos arbitrais baseados no pleito de acionistas 
minoritários estrangeiros. Em comunicado emitido pelo Ministério de Economia e Produção (2004), o governo contesta o próprio sistema sem qualquer controle de enquadramento das reclamações junto ao CIRCI. Sublinha que o Banco Mundial iniciou processo de revisão e atualização do sistema de arbitragem, diante das críticas ao CIRCI. Nesse documento, o Ministério ressalta que se deve levar em conta que os laudos arbitrais ditados no âmbito do CIRCI precisam ser executados na Argentina como se fossem sentenças locais.

Em função disso e conforme sustenta a doutrina cristalizada da Corte Suprema e reiterada no caso Cartellone $e^{40}$, os tribunais exercem certo controle judicial quando laudos arbitrais contrariem a ordem pública e sejam inconstitucionais, ilegais ou sem embasamento, bem como quando forem prolatados em violação das condições ou das formas impostas pelas partes. Ainda a respeito dessa questão, os defensores da Argentina no caso CMS argüiram nas fases orais do procedimento do CIRCI em Paris que os tratados bilaterais não se sobrepõem à Constituição Nacional e, portanto, uma companhia não pode invocar tratado na tentativa de evitar o julgamento das cortes locais argentinas. Ademais, uma companhia prestadora de serviços públicos não poderia impor a limitação do direito soberano do governo em modificar a política econômica ou as tarifas públicas. Muitos analistas acreditam que a contestação dos laudos arbitrais prolatados sob os auspícios do CIRCI pela justiça local argentina é apenas manobra, a fim de pressionar as empresas a renegociar os contratos ou amenizar as demandas.

Seja como for, para os defensores da Argentina, mesmo que os tratados estejam em patamar superior às leis, devem subordinar-se à Constituição Federal conforme disposto no artigo 27 da Carta Magna: “El Gobierno Federal está obligado a afianzar sus relaciones de paz y comercio con las potencias extranjeras por medio de tratados que estén en conformidad con los principios de derecho público establecidos en esta Constitución”. Por isso, a defesa reside no princípio constitucional de que os tratados internacionais se subordinam à Constituição da Argentina. Assim, para a execução dos laudos, é necessário que estejam de acordo com os princípios de direito público doméstico. Apesar de a Convenção criadora do CIRCI, da qual a Argentina é signatária, estipular que os laudos equivalem à coisa julgada, é inadmissível a execução por tratar-se de laudos que ferem a ordem pública e os princípios de direito público argentinos.

\footnotetext{
${ }^{40}$ Na decisão “Jose Cartellone Construcciones vs. Hidroelectrica Norpatagonica S.A.”, a Corte Suprema Federal da Argentina julgou que as cortes locais podem revisar laudo arbitral concedido sob as regras do CIRCI, mesmo quando as partes no litígio tenham acordado dispensar o direito à apelação, se o laudo contrariar o interesse público, pelo mesmo motivo, as decisões arbitrais podem ser contestadas judicialmente quando inconstitucionais, ilegais ou não-razoáveis.
} 
Ao contrário do que o caso Cartellone apregoa, a Convenção de Washington no artigo 53 expressamente veda a possibilidade de qualquer recurso não previsto no tratado. Trata-se de afastar a revisão do laudo pela lei local, corroborado pela jurisprudência do Tribunal $^{41}$. Já foi pacificado o entendimento de que o direito internacional prevalece em caso de conflito ou lacuna do direito local tanto pela Constituição argentina, cujo teor do artigo 75, inciso 24 considera os tratados superior às leis, e apenas abaixo da constituição na hierarquia legislativa, quanto em diversos casos no $\mathrm{CIRCI}^{42}$. Em função disso, a defesa propugnada pela Argentina não pode prosperar.

Ainda a esse respeito, qualquer violação do que foi convencionado no plano externo enseja responsabilidade internacional do Estado argentino conforme a redação do artigo 27 da Convenção de Viena sobre Direito dos Tratados, do qual, além de a Argentina ser signatária $^{43}$, é também alçada à categoria de norma consuetudinária. O citado artigo reza que: "uma parte não pode invocar as disposições de seu direito interno para justificar o descumprimento de um tratado”.

Por meio do marco legal instituído pelos APPIs e pela acessão ao CIRCI, reforçou-se o compromisso já existente de o Estado não formular políticas de restrição às concessões públicas sem a contrapartida de ressarcimento pelos danos sofridos, em virtude da quebra contratual. Qualquer ato considerado expropriatório enseja demandas dos investidores no plano arbitral e conclama a insegurança jurídica do sistema legal argentino. Na prática, não se trata de impedir a Argentina de exercer o direito soberano de expropriar a propriedade para fins de ordem pública. Trata-se, no entanto, de prestar a devida indenização, cujo compromisso foi reforçado pela ratificação dos APPIs.

Ao esposar tese controversa, o governo aumenta a insegurança jurídica na Argentina não apenas pelas expectativas frustradas daqueles que tiveram a desvalorização brutal do que haviam economizado ao longo de uma vida inteira e dos investidores, mas também pelos entendimentos adotados pela Corte Suprema argentina, ao endossar as normas emanadas pelo Executivo em contraposição à proteção de liberdades e garantias constitucionais. Trata-se da degradação do arcabouço jurídico e da confiança nas instituições da nação erigidos ao passar dos anos.

\footnotetext{
${ }^{41}$ Decisão sobre anulação “Mine v. Guinea” de 22 de dezembro de 1989.

${ }^{42}$ Cf. decisões: "Klöckner vs. Camerões”; “Amoco vs. Indonésia”; "LETCO vs. Libéria” e "SPP vs. Egito”.

${ }^{43}$ A Argentina assinou a Convenção de Viena sobre Direito dos Tratados em 30 de janeiro de 1987 e ratificou-a em 17 de agosto de 1990.
} 
No afã de construir estratégia de defesa a qualquer custo, surgem as mais variadas teses. Nessas circunstâncias, Alfaro \& Lorenzi (2005) advogam teoria radical para a proteção do Estado argentino, cujo cerne apregoa a ilegalidade da jurisdição do CIRCI no que diz respeito às demandas contra o país. De acordo com a interpretação do artigo 75, inciso 24, corresponde ao Congresso Nacional:

“Aprobar tratados de integración que deleguen competencia y jurisdicción a organizaciones supraestatales en condiciones de reciprocidad e igualdad, y que respeten el orden democrático y los derechos humanos. Las normas dictadas en su consecuencia tienen jerarquía superior a las leyes. La aprobación de estos tratados con Estados de Latinoamérica requerirá la mayoría absoluta de la totalidad de los miembros de cada Cámara. En el caso de tratados con otros estados, el Congreso de la Nación, con la mayoría absoluta de los miembros de cada Cámara, declarará la conveniencia de la aprobación del tratado y sólo podrá ser aprobado con el voto de la mayoría absoluta de la totalidad de los miembros de cada Cámara, después de ciento veinte días del acto declarativo. La denuncia de los tratados referidos a este inciso, exigirá la previa aprobación de la mayoría absoluta de la totalidad de los miembros de cada Cámara.”.

Assim, como a Argentina apenas aderiu ao CIRCI em 28 julho de 1994, pela Lei 24.353, promulgada em 22 de agosto de 1994 e publicada no Diário Oficial em 2 de setembro de 1994, ou seja, posterior à reforma constitucional de 24 de agosto de 1994, faltaria a aprovação do Congresso. No entanto, essa estratégia não foi seguida pelo governo que pretende utilizar as cortes domésticas para declarar os laudos nulos. Desse modo, as autoridades agiram de maneira prudente, pois a sustentação dessa tese ocasionaria verdadeiro caos jurídico no país, o que, por sua vez, agravaria, ainda mais, o descrédito na eficácia do sistema jurídico por parte dos investidores estrangeiros e da sociedade internacional.

Seja qual for a argumentação do governo argentino, é preciso lembrar que a submissão dos laudos arbitrais do CIRCI ao controle de constitucionalidade da Corte Suprema Argentina viola o artigo 27 da Convenção de Viena sobre os Direitos dos Tratados de 1969, que estipula não se poder invocar o direito interno, a fim de eximir-se de obrigação internacional sem ensejar responsabilidade. É importante sublinhar que nenhum laudo sob os auspícios do CIRCI foi rejeitado até o presente. Tal medida deve aumentar a insegurança jurídica e aumentar o custo-país, pois foi a submissão ao sistema arbitral sem questionamento o fator que ajudou a atrair o capital externo. 
Em tese, se, por um lado, a jurisprudência e a doutrina internacionais não apóiam a tese de defesa argentina, por outro, o laudo Eudoro A. Olguín v. República do Paraguai ${ }^{44}$ parece ser o primeiro a respeito de investimentos estrangeiros que lida com medidas de emergência tomadas por Estados e assume posicionamento distinto da corrente dominante. Nessa oportunidade, o tribunal arbitral concluiu que o texto do APPI não contém qualquer regra que obrigue o Estado, em cujo território foi realizado o investimento, a garantir o pagamento do investimento no evento de uma crise financeira (§ 70-75) ${ }^{45}$. Acrescenta que, embora seja salutar o estabelecimento de regras que imponham sanções aos Estados que fracassem em monitorar de forma responsável suas entidades financeiras, a verdade é que tais regras não existem tanto sob o direito paraguaio quanto nas disposições do APPI, nem na maioria dos países da região.

Esse argumento pesa na defesa argentina, na medida em que se orienta no sentido de provar regime de exceção, dada a grave crise financeira que assolou o país. Se essa linha de ação na estratégia da Argentina redundar em êxito, ainda não se pode saber. Resta averiguar o caráter temporário da referida crise, pois não se vislumbra, no futuro próximo, a volta da paridade cambial. Tampouco se cogita a manutenção dos contratos corrigidos pelo dólar estadunidense nem indexados pelo PPI. Nesse contexto, a recente prolatação do laudo CMS pode orientar as futuras decisões nos casos envolvendo a Argentina e balizar o entendimento jurisprudencial no âmbito do CIRCI a respeito do assunto.

\section{O LAUdO CMS GÁS TRANSMISSION COMPANY E SUAS POSSÍVEIS IMPLICAÇÕES}

No caso CMS Gás Transmission Company vs. República Argentina ${ }^{46}$, o demandante questiona o poder regulatório do Estado ao requerer indenização por modificações no sistema tarifário. No litígio em tela, a CMS, empresa incorporada sob as leis

\footnotetext{
${ }^{44}$ Caso n. ARB/98/5.

${ }^{45}$ De acordo com o tribunal: “... The scope of the Bilateral Investment Treaties was categorically specified in the award issued in the arbitration proceedings between Emilio Agustín Maffezini and the Kingdom of Spain (ICSID Case n. ARB/97/7). That award, rendered by a distinguished Arbitral Tribunal on November 13, 2000, stated, in paragraph 64: ... the Tribunal must emphasize that Bilateral Investment Treaties are not insurance policies against bad business judgments.”

${ }^{46}$ Caso n. ARB/01/08 “CMS Gas Transmission Company v. Argentina” registrado em 24 de maio de 2001, cujo laudo foi expedido em 12 de maio de 2005. O tribunal foi composto pelos árbitros: Francisco Orrego Vicuña (Chile), na qualidade de presidente, Marc Lalonde (Canadá) e Francisco Rezek (Brasil).
} 
dos Estados Unidos, adquiriu 29,42\% das ações da empresa “Transporadora de Gas del Norte S.A.” (doravante “TGN”) e contestou a medida de suspensão dos reajustes das tarifas de transporte de gás, segundo convencionado no contrato de concessão, ou seja, indexação conforme o PPI dos Estados Unidos e correção atrelada ao dólar norte-americano.

Por tratar-se do primeiro caso em que a Procuradoria do Tesouro Nacional versou não apenas sobre a jurisdição do Centro, mas também acerca das questões de fundo, por intermédio da análise do laudo, pode-se inferir qual será a estratégia de defesa pautada pela Argentina nas outras ações que correm perante o CIRCI em razão da pesificação e da Lei de Emergência. O que balizou, em termos gerais, as diretrizes de defesa ao longo do caso foi a rejeição maciça em relação à viabilidade da apresentação da demanda, ao objetar a jurisdição do Centro. Para tanto, questionaram-se os seguintes aspectos: a necessidade do esgotamento dos recursos internos antes de recorrer-se à arbitragem internacional; o caráter de acionista minoritário do demandante; a inviabilidade de contestar decisões soberanas emanadas pelo Estado.

No tocante a essa linha de ação seguida na maioria das reclamações contra o país, a defesa redundou em fracasso à medida que os tribunais arbitrais vêm a aceitar a jurisdição do CIRCI nos casos apresentados contra a Argentina. Quanto à estratégia referente à necessidade do esgotamento dos recursos internos, torna-se factível apenas quando os investidores se encontram despojados do devido processo legal na instância local. Sobretudo, após o APPI firmado com a França, corroborada pela decisão no caso Maffezini, tal assertiva não pôde prosperar, uma vez que se permitiu a opção do acesso direto ao tribunal internacional. Existe distinção em obrigações derivadas de tratado e de contrato. Quando se baseia no pedido de reparação da primeira, a opção pela arbitragem torna-se viável.

No que diz respeito à questão da desconsideração do acionista minoritário como investidor, a defesa carece de fundamento, em primeiro lugar, porque a maioria dos APPIS celebrados pela Argentina, entre eles, o firmado com os Estados Unidos, prevê definição ampla do conceito de investidor, ao reconhecer, nessa qualidade, o mero detentor de ações. Em segundo lugar, grande parte da jurisprudência endossa a tese de que os acionistas minoritários têm jus standi perante o CIRCI.

Por fim, em relação à última argumentação da Procuradoria do Tesouro Nacional acerca do estado de emergência econômica, a priori, esse aspecto parece ser o único com potencial aceitação, dado o reconhecimento tanto pelos APPIS quanto pela prática 
internacional como situação excludente ${ }^{47}$. Ao sustentar que as medidas públicas de política econômica foram tomadas de forma geral, tanto para cidadãos argentinos quanto para estrangeiros sem caráter discriminatório, a Procuradoria revela que não houve a violação dos princípios de tratamento justo e eqüitativo, tampouco o de não-discriminação. Aduz, ainda, à contestação de que ações perpetradas sob as disposições da Lei de Emergência são dotadas de caráter geral e não-aplicáveis apenas a investimentos. Desse modo, afasta-se a jurisdição do Centro, já que versa sobre matérias distintas de investimentos.

Em tese, no entanto, o reconhecimento de estado de emergência não implica desconhecimento dos direitos dos investidores, tampouco o reconhecimento das perdas enfrentadas por esses investidores no momento da quebra da conversibilidade. Ao transferir os riscos do fim do regime cambial para o governo, os contratos firmados com os investidores possibilitam fundamentar as demandas na perda do valor investido, tal qual fez a CMS.

No que diz respeito à jurisdição, o tribunal concluiu que não pode avaliar as regras de política econômica gerais implementadas pela Argentina. Em compensação, pode examinar se normas específicas afetam o investimento estrangeiro realizado. Com o laudo, na prática, houve a corroboração do entendimento a respeito da jurisdição do CIRCI e a competência do Tribunal nos casos argentinos. Vale citar o § 33 do referido documento:

“33. Sobre a base dessas considerações, o Tribunal conclui nesse aspecto que não tem jurisdição sobre medidas gerais de política econômica adotadas pela República Argentina e que não pode emitir juízo sobre se elas são certas ou equivocadas. No entanto, o Tribunal também conclui que tem jurisdição para examinar se medidas específicas afetam o investimento realizado pelo demandante ou medidas gerais de política econômica, que tem uma relação direta com esse investimento que tenham sido adotadas em desacordo aos compromissos juridicamente obrigatórios assumidos com o investidor mediante os tratados, a legislação ou os contratos.”[tradução livre]

Ao decidir o mérito do caso, o tribunal condenou a República Argentina a compensar as perdas da CMS no montante de US\$ 133 milhões, cujo valor somado aos juros do período alcança a soma de US\$ 149 milhões. Trata-se de valor inferior ao solicitado pela demandante de US\$ 260 milhões. Quando expediu o laudo, o tribunal julgou que a Argentina

\footnotetext{
${ }^{47}$ Para embasar a tese, o demandado invocou o caso Gould Marketing, Inc., no qual o Tribunal de Reclamações Irã-Estados Unidos sustentou que: "los perjuicios causados como consecuencia de fuerzas sociales y económicas que el Estado no podía controlar mediante su debida diligencia, "no son atribuibles al Estado a los efectos de responder por daños."
} 
violou as obrigações derivadas do $\mathrm{APPI}^{48}$, ao romper unilateralmente com as disposições regulatórias a respeito do regime de correção e de indexação das tarifas de transmissão de gás da TGN.

Embora o tribunal considere perdas no valor investido pela CMS de, aproximadamente, 95\%, não baseou o laudo em expropriação ${ }^{49}$. Em vez disso, invocou a violação do artigo II(2)(a) do APPI entre Argentina e Estados Unidos, que contempla o tratamento justo e eqüitativo, ao impor atos arbitrários e desrespeito dos compromissos assumidos diante dos investidores estrangeiros, referentes a memorandos de oferta, leis, regulações e à própria concessão ${ }^{50}$. Ao mesmo tempo, o tribunal rejeitou os argumentos constitucionais argentinos e afirmou que a Carta Magna dessa nação reconhece, de forma expressa, as obrigações provenientes de tratados internacionais. Nessas circunstâncias, não se podem aceitar as ações referentes ao estado de emergência econômica ${ }^{51}$ e conclui-se que a Argentina é responsável pelos atos de transgressão do tratamento justo e eqüitativo sob a vigência da Lei de Emergência, ainda que não tenha incorrido em discriminação entre

\footnotetext{
${ }^{48}$ No preâmbulo do Tratado, estabeleceu-se, de maneira clara, que a proteção referente ao tratamento justo e eqüitativo tem como objetivo principal "mantener un marco estable para las inversiones y la utilización más eficaz de los recursos económicos.” Com efeito, não há dúvida de que a estabilidade jurídica e comercial é elemento intrínseco do tratamento justo e eqüitativo.

${ }^{49} \mathrm{O}$ tribunal considerou que nenhum tipo de transferência de propriedade, tampouco nenhuma medida adotada constituíram ingerência equivalente à expropriação. Conforme o laudo: "En el caso Pope \& Talbot el tribunal se ocupó detalladamente de la privación sustancial. El Gobierno argentino ha alegado convincentemente que los aspectos que deben tenerse en cuenta para establecer la existencia de privación sustancial, según se estableció en ese caso, no se encuentran presentes en esta controversia. En efecto, el Demandado ha explicado que el inversionista ejerce el control de la inversión; el Gobierno no administra las operaciones diarias de la empresa; y el inversionista tiene la plena propiedad y el control de la inversión.”

${ }^{50}$ O demandante, segundo narrado nos parágrafos 268 e 269, aduziu casos análogos de violação do tratamento justo e eqüitativo, a saber: "El Demandante cita las opiniones de varios juristas destacados así como decisiones que enfatizan la importancia de este requisito, con particular referencia al caso CME, en el que se concluyó que "[El Gobierno] contravino su obligación de trato justo y equitativo al dejar sin efecto los arreglos en que descansó el inversionista extranjero para realizar la inversión." El Demandante también fundamenta su reclamo en la siguiente conclusión del tribunal en el caso Técnicas Medioambientales Tecmed c. México, en cuanto a que un trato justo y equitativo "...exige de las Partes Contratantes del Acuerdo brindar un tratamiento a la inversión extranjera que no desvirtúe las expectativas básicas en razón de las cuales el inversor extranjero decidió realizar su inversión...”

${ }^{51}$ O art. IV(3) do APPI entre Argentina e Estados Unidos dispõe: "A los nacionales o sociedades de una Parte cuyas inversiones sufran pérdidas en el territorio de la otra Parte con motivo de guerra o de otro conflicto armado, revolución, estado de emergencia nacional, insurrección, disturbio civil o cualquier otro acontecimiento similar, la otra Parte les otorgará un trato no menos favorable que el trato más favorable que otorgue a sus propios nacionales o sociedades o a los nacionales o sociedades de terceros países, respecto de las medidas que adopte con relación a tales pérdidas".
} 
estrangeiros e nacionais ${ }^{52}$. Tampouco se pode questionar se as medidas seriam permanentes ou temporárias. Por extrapolar qualquer período razoável de tempo, tão-somente se pode aferir que tenham perdido o caráter transitório.

Na medida em que o objeto precípuo dos tratados sobre investimentos seja a proteção contra riscos políticos e dificuldades econômicas, o interregno que compreende o período da eclosão da crise econômica até os dias de hoje não configura estado de emergência. Além disso, a crise aguda não pode equiparar-se ao colapso total, o qual ensejaria o estado de necessidade ${ }^{53}$ ou força maior ${ }^{54}$. Sob o ponto de vista jurídico, portanto, deve levar-se em conta a necessidade de indenização, pois a ilicitude do ato não foi excluída ou deixou de existir.

Outra contestação inócua por parte da Procuradoria do Tesouro Nacional, referese ao fato de a legislação de gás dispor que a tarifa do fornecimento deva ser justa e razoável, o que não se sustentaria em contratos dolarizados em contexto de recessão. Quando celebrou os contratos de concessão, entretanto, a República Argentina negociou todos os termos e aceitou, de forma expressa, tal norma. Ao rechaçar, posteriormente, o estipulado, atenta contra o princípio da boa-fé, consagrado tanto na esfera nacional quanto no plano internacional. Por mais que a defesa argentina queira provar o contrário, denotam-se a responsabilidade e o dever de indenizar por parte do Estado argentino.

Com o advento da decisão CMS, a Argentina perde espaço de negociação frente aos investidores estrangeiros. De resto, norteia as demandas restantes no âmbito do CIRCI.

\footnotetext{
${ }^{52}$ Embora o APPI entre a Argentina e os Estados Unidos contenha disposições acerca do assunto, ao permitir a aplicação de atos para a manutenção da ordem pública, consoante o art. XI: "El presente Tratado no impedirá la aplicación por cualquiera de las Partes de las medidas necesarias para el mantenimiento del orden público, el cumplimiento de sus obligaciones para el mantenimiento o la restauración de la paz o seguridad internacionales, o la protección de sus propios intereses esenciales de seguridad".

${ }^{53} \mathrm{O}$ art. 25 dos artigos sobre responsabilidade estatal por atos ilícitos internacionais elaborados pela Comissão de Direito Internacional da ONU estipula normas a respeito de quando se configura o estado de necessidade: "1. Ningún Estado puede invocar el estado de necesidad como causa de exclusión de la ilicitud de un hecho que no esté de conformidad con una obligación internacional de ese Estado a menos que ese hecho: a) sea el único modo para el Estado de salvaguardar un interés esencial contra un peligro grave e inminente; y b) no afecte gravemente a un interés esencial del Estado o de los Estados con relación a los cuales existe la obligación, o de la comunidad internacional en su conjunto. 2. En todo caso, ningún Estado puede invocar el estado de necesidad como causa de exclusión de la ilicitud si: a) la obligación internacional de que se trate excluye la posibilidad de invocar el estado de necesidad; o b) el Estado ha contribuido a que se produzca el estado de necesidad".

${ }^{54}$ Consoante as próprias palavras dos árbitros no $§ 217$ do laudo: “A la luz de este análisis, el Tribunal tiene el convencimiento de que el principio del estado de necesidad previsto en el derecho interno no ofrece una excusa cuando las medidas en cuestión dan lugar a una modificación sustancial o esencial de los derechos contractualmente adquiridos, en especial si la aplicación de esas medidas supera un plazo estrictamente definido."
} 
Basta verificar os casos sob julgamento do Centro, para notar o impacto no erário público da nação Argentina, já tão defasado em função da crise. Ainda que a defesa possa intentar anular o laudo por meio de recurso previsto na Convenção, o que parece pretender fazer, a reversão do julgamento será difícil.

Seja qual for o futuro das reclamações, os formuladores da política econômica e externa do Brasil devem considerar a experiência argentina. Se foi acertada a decisão de rejeitar a acessão ao CIRCI na qualidade de membro, ainda é difícil mensurar. Trata-se de assunto sensível à política externa. Qualquer tentativa de vinculação a jurisdições internacionais, sempre foi considerada com reservas por sucessivos governos. Ao vincular-se ao sistema arbitral proposto pelo CIRCI, o país aceitará diversos postulados relacionados à proteção do investidor estrangeiro.

Se, por um lado, trará maior segurança e, por sua vez, o potencial de maior fluxo de IED, por outro, cerceia a política econômica, ao pautar-se por normas, tais como, a nãodiscriminação de estrangeiros, a impossibilidade de impor índices de nacionalização ou de desempenho para os produtos produzidos por empresas transnacionais. Se, por um lado, os condutores da política econômica julgarem convenientes esses mecanismos, sem dúvida, incorreram em erro, ao firmarem compromissos arbitrais, por outro lado, deve-se considerar que recorrer a instrumentos discriminatórios não só iria de encontro a normas internacionais mas também à legislação doméstica.

Tendo em mente, contudo, que o Brasil apresenta características distintas da Argentina em termos macroeconômicos mais sólidos e ambiente econômico mais estável e que pode prescindir de instrumentos discriminatórios na medida em que possui vantagens comparativas e competitivas superiores ao país vizinho, talvez se deva considerar maior comprometimento internacional no que diz respeito à proteção do investidor estrangeiro. Nunca é demais lembrar, em contraste, que o país se torna, cada vez mais, investidor na região seja por meio de investimentos decorrentes de suporte governamental, como os provenientes do Banco Nacional de Desenvolvimento Econômico e Social (BNDES), seja por intermédio de empresas privadas. Como parte da diretriz da política externa recente, a América do Sul transformou-se em prioridade; também se defende maior entrosamento com países do continente africano.

Trata-se de nações, cuja estabilidade política ainda é delicada, e grande parte delas já são membros do Centro. Por isso, a acessão do Brasil ao CIRCI dotaria o cidadão brasileiro de proteção contra riscos não-comerciais. Cabe aos formuladores de políticas públicas 
verificar a mudança no perfil de inserção internacional do País e traçar estratégias condizentes com essas alterações. Em face do advento de conflitos na Bolívia e da constante instabilidade em países africanos, por exemplo, o CIRCI surge como alternativa viável para o reforço da proteção de investidores brasileiros no exterior. Além disso, a ratificação da Convenção de Washington não implica a jurisdição imediata do Centro, que deve, por sua vez, ser assentada em outro compromisso expresso. Com a expedição do laudo CMS, há mais elementos para a avaliação do Centro por parte dos condutores da política externa do Brasil.

\section{CONSIDERAÇÕES FINAIS}

Em virtude da proliferação de tratados bilaterais de investimento, a tendência é que, cada vez mais, sejam comuns controvérsias sobre investimento. O CIRCI aparece como instância natural para a resolução de conflitos relativos ao IED. Embora autores defendam que análise mais apurada dos dispositivos da Convenção demonstra que se procurou encontrar balanço razoável entre as obrigações de investidores e os Estados receptores, há diversas críticas ao Centro. É claro que os países em desenvolvimento sofrem pressões em abrir mão de suas prerrogativas de soberania e aderir às regras do Centro pelas grandes corporações transnacionais, sob pena da interrupção do fluxo de investimento. Há, portanto, certa coação a fim de que Estados acedam à Convenção do CIRCI, respeitem os princípios de proteção dos investidores e não releguem as disposições da política econômica e industrial ao bel-prazer dos governantes.

Até a eclosão da crise, a República Argentina foi objeto de poucas reclamações junto ao Centro, cuja maioria foi solucionada por via negociadora. Apenas quando houve a alteração radical no que foi estipulado em contratos de concessão firmados com empresas transnacionais, com graves prejuízos às concessionárias e sem perspectivas de indenização ou reversão das medidas, é que se recorreu à arbitragem.

Com o advento da condenação da Argentina no laudo CMS, a situação deteriorase, na medida em que as futuras decisões devem apoiar-se no que foi julgado pelos árbitros. Trata-se de penas cujo montante é significativo para uma economia em crise, como a Argentina. Desse modo, seria salutar aos governantes do país envidar esforços e empreender iniciativas no sentido de renegociar os contratos e propor reparações aos danos sofridos pelos investidores. Ao que parece, tais ações já foram iniciadas com a criação da UNIREN e da UNADAR. No entanto, a atitude ambígua do governo argentino, ora na busca de solução 
negociadora, ora na invocação de cânones nacionalistas, na simples rejeição dos laudos e no não-pagamento das penas, não colabora com a resolução do problema.

Durante os primeiros cinco anos do sistema de conversibilidade, a Argentina experimentou significativo crescimento do PIB com inflação baixa. No entanto, cabe ressaltar que havia incompatibilidade entre o déficit público, a inflação e o câmbio fixo, no qual o primeiro foi financiado, por muito tempo, com os recursos das privatizações, de investimentos externos diretos e pelo aumento da dívida pública. Ao final da década, a situação tornou-se insustentável na medida em que os recursos que financiavam e davam sustentáculo ao sistema de conversibilidade escassearam, no caso do investimento externo direto e da possibilidade de recorrer-se ao mercado internacional com vistas a obter divisas, ou extinguiram-se por completo, no caso da possibilidade de novas privatizações. Fica demonstrado o erro que se configura na manutenção por longo prazo da sobrevalorização do câmbio: a Argentina pagou alto preço, por não flexibilizar seu câmbio e insistir no sistema de currency board.

No que diz respeito ao Mercosul, a crise Argentina constitui-se como um dos maiores desafios já enfrentados pelo bloco, que se encontra numa encruzilhada. Se, por um lado, existe o risco do retrocesso à zona de livre-comércio, por outro, talvez, isso ajude a leválo ao aprofundamento, porque, se já houvesse estruturas supranacionais, haveria maior disciplina e consenso entre os membros. Assim, a Argentina não poderia ter tomado tantas medidas unilateralmente e pensar só a curto prazo e no âmbito nacional em vez do regional em relação ao bloco. Ademais, adquire relevância a necessidade de configurarem-se políticas comuns na área de IED. Não se concebe mercado comum entre países cuja legislação na área de investimentos seja tão díspare quanto na área do Mercosul.

Quanto às reclamações junto ao CIRCI, a Argentina deve adotar posição mais pragmática. Enquanto o Estado argentino não se sentir compelido por suas próprias regras jurídicas, de maneira que cada nova crise no horizonte redunde no uso da doutrina de emergência ao quebrar direitos adquiridos por contratos privados e administrativos ou por sentenças firmes, em virtude das exigências impostergáveis do bem comum ou do interesse geral da população, o país será rotulado como de risco alto para IED. Não se pode atribuir aos investidores a irresponsabilidade dos governantes argentinos ao celebrar contratos cuja indexação estava atrelada a índice de outro país e cujo reajuste se baseava no dólar estadunidense.

Por tratar-se de demandas similares, a defesa Argentina deveria buscar solução conjunta. Ao delinear ação baseada no fato de que a situação do país requeira medidas 
excepcionais, a Argentina incorre em erro, e seus argumentos não podem prosperar na medida em que as medidas tomadas se transformaram em permanentes. Mais do que subterfúgios, a Argentina deve reconhecer que suas ações ocasionaram perdas aos investidores e procurar obter solução benéfica para ambas as partes, pois é certa a penúria por que passa o povo.

Com base na experiência Argentina no CIRCI, cabe aos formuladores da política econômica do Brasil analisar os aspectos positivos e negativos do período com vistas a traçar parâmetros a fim de que, nos próximos anos, haja apropriada harmonização da política sobre investimentos na região. Ainda é importante considerar as razões dos pleitos dos investidores junto ao CIRCI, no intuito de avaliar potencial acessão brasileira ao Centro.

\section{REFERÊNCIAS}

ÁVILA, Gabriela Alvarez. Las características del arbitraje del CIADI. Anuário Mexicano de Derecho Internacional, [S.l.], v. 2, 2002.

BACHAND, Rémi. Les poursuites CIRDI contre l'Argentine: quand la gestion publique se heurte aux droits des investisseurs étrangers. Notes de recherche - CEIM 2005. Disponível em: <www.er.uqam.ca/nobel/ieim/img/pdf/cahierderecherche.pdf> Acesso em: 20 de out. 2005.

BELLO, Teresinha da Silva. Algumas considerações sobre a crise Argentina. Indicadores Econômicos FEE, Porto Alegre, v. 30, n. 2, set. 2002.

BLACKLABY, Nigel. El arbitraje según los tratados bilaterales de inversión y tratados de libre comercio en América Latina. Revista Internacional de Arbitraje, jun./dic., 2004.

BLÁZQUEZ, Jorge; SEBÁSTIAN, Miguel. El impacto de la crisis argentina sobre la economía española. [S.l.]: Real Instituto Elcano de Estudios Internacionales y Estratégicos, 2003. (Documento de Trabajo n. 12/2004).

BIDART, Germán J. Campos. Manual de la constitución reformada. Buenos Aires: Ed. Ediar 1998.

BISANG, Roberto; Gómez, Georgina. Las Inversiones en la industria argentina en la década de los noventa. Santiago: CEPAL, 1999. (Serie Reformas Económicas, n. 41)

BURGUER, Mariana Bomfim. Estudo sobre a parcialidade das sentenças proferidas no âmbito do ICSID. 2004. Dissertação (Mestrado)- UFMG: Belo Horizonte, 2004.

CAMPAÑA, Germán González. La rescisión y modificación unilateral de los contratos administrativos frente a los tribunales arbitrales del CIADI. Buenos Aires: La Ley, 2004. 
CREMEADES, Bernardo M.; CAIRNS, David J.A. La seguridad jurídica de las inversiones extranjeras: la protección contractual y de los tratados. Revista Internacional de Arbitraje, jun.-dez. 2004.

FERRER, Aldo. La economia argentina: desde sus orígenes hasta princípios del siglo XXI. Buenos Aires: Fondo de Cultura Económica, 2004.

KULFAZ, Matias; PORTA, Fernando; RAMOS, Adrián. Inversión extranjera y empresas transnacio nales en la economía argentina. Buenos Aires: CEPAL, 2002. (Serie Estudios y Perspectivas, n. 10).

MACCHIA, Valéria; MARTÍNEZ, José A. La doctrina del fallo cartellone: resulta aplicable a los laudos del CIADI? Setembro de 2004. Disponível em:

<www.eldial.com/bases/doctri/notas/nt041007.asp> Acesso em: 18 de jul. 2005.

MACHADO, Luis Fernando Corrêa da Silva. Investimento estrangeiro direto: o "lugar" da assinatura de acordos internacionais na política econômica do Brasil na década de 1990. 2005. Dissertação (Mestrado)- Instituto de Relações Internacionais, Universidade de Brasília: Brasília, 2005.

MAREGA, Flávio. Solução de controvérsias investidor estrangeiro-estado. 2005. (Tese de CAE) - Instituto Rio Branco: Brasília, 2005.

SCHREUER, Christopher H. The ICSID convention: a commentary. Cambridge: Cambridge University Press, 2001.

SHASTER, Oscar. Compensation for expropriation. American Journal of International Law, Washington, 1984.

SOARES, Guido. Órgãos das soluções extrajudiciárias de litígios. São Paulo: Revista dos Tribunais, 1985.

SORNARAJAH, M. The International Law on Foreign Investment. London: Cambridge University Press, 2000. 2001. . The settlement of foreign investment disputes. The Hague: Kluwer Law International,

STANLEY, Leonardo E. Acuerdos bilaterales de inversión y demanda ante tribunales internacionales: la experiencia argentina reciente. CEPAL: Santiago, 2004. (Serie Desarrollo Productivo, n.158).

TAWIL, Guido Santiago. Los conflitos em matéria de inversión, la jurisdicción del CIADI y el derech aplicable: a propósito de las recientes decisiones en los casos "Vivendi", "Wena" y “Maffezini”. Revista Argentina del Régimen de la Administración Pública, n. 289 ano 25, Buenos Aires, Ediciones RAP S.A., oct. 2002. 
TEMPONE, Rubén Eduardo. Protección de inversiones extrangeiras. Buenos Aires: Ed.

Ciudad Argentina, 2003.

VIDELA, Esteban M. Ymaz. Protección de inversiones extranjeras: tratados bilaterales sus efectos en las contrataciones administrativas. Buenos Aires: La Ley, 1999.

Prismas: Direito, Políticas Públicas e Mundialização

http://www.mestrado.uniceub.br/revistamestrado/

Artigo recebido em 08/02/2006 e aceito para publicação em 15/05/2006

A revista Prismas: Direito, Políticas Públicas e Mundialização destina-se à publicação de artigos relacionados com a área jurídica, tem o propósito de difundir as reflexões dos pesquisadores, docentes, discentes, profissionais e estudantes da área de Ciências Jurídicas.

Os artigos são avaliados mediante processo de revisão por pares e deverão contemplar as reflexões que dizem respeito ao estudo do Direito, das Relações Internacionais e das Políticas Públicas. 